\title{
sciendo
}

\section{THE ROLE OF THE UNIVERSITIES IN SHAPING THE ENTREPRENEURIAL ECOSYSTEM. A QUALITATIVE APPROACH}

\author{
Diana Manuela, LINA \\ „Alexandru Ioan Cuza” University of Iași, Economy and Business Administration Faculty, Economy and Business Administration \\ Doctoral School, Iași, Romania, lina.diana@gmail.com
}

\begin{abstract}
Studies addressing the concept of entrepreneurial ecosystem generally focus on identifying its constituent elements and less on the interaction between them. To fill this gap, the study's objective is to explore the interaction between the university and the other components of the entrepreneurial ecosystem, from a semantic perspective. Using the method of qualitative analysis, respectively the semantic analysis method, the study analyses the role of universities from the North East region of Romania in creating the regional entrepreneurial ecosystem through the influence of regional development strategies. The tools used to achieve the proposed objective were bibliometric analysis and the Tropes software. The obtained results reflect the increased interest of the researchers towards the university and its role in the entrepreneurial development of the communities. On the other hand, regional policy documents do not reflect (at least at semantic level) the role that universities have in creating the regional entrepreneurial ecosystem.
\end{abstract}

\section{INTRODUCTION}

How can a stimulating environment for enterprise development be created in general and for entrepreneurship in particular? This question has begun to concern the politicians of governments since the 1970s. David Birch, (Birch, 1979) notes that small businesses are the ones that generate the most jobs in the US, recommending the government to promote policies to support small businesses. The success of Silicon Valley remains a reference example for increasing the competitiveness of companies, the collaboration with universities and the local government. Traditional boundaries between businesses, labor and entrepreneurship are increasingly changing as a result of transformations in contemporary society. Developing information technology, increasing the overlapping connectivity over the slower wage growth compared to rising costs of life lead to changes in the nature of employment relationships between the employee and the employer.

How can connection between stakeholders (institutions and individuals) interact in the development of entrepreneurship, at the level of a region, regions? Increasingly, entrepreneurship is addressed in a systemic, interdisciplinary way. In this context, the entrepreneurial ecosystem is a new representation of the interaction between the economic and social environment that influences the local entrepreneurship.

The question addressed by this study is: from a semantic approach does the North-East Regional Strategy for Research and Innovation through Smart Specialization RIS 3, Romania, recognize the role played by the universities in the North East region of Romania in configuring the entrepreneurial ecosystem?

Using the method of qualitative analysis, a semantic analysis was carried out for the Romanian version of "North-East Regional Strategy for Research and Innovation through Smart Specialization RIS 3". After we set up the analysis units (North East region of Romania), we choose of a set of categories
(REDI pillars and interaction with the university), then proceed to analysis of the relations of the references used, and synthesis of the conclusions. For this purpose we used the TROPES v.8.2 semantic analysis program.

The literature review shows a growing interest (especially since 2010) for the holistic approach to the concept of entrepreneurial ecosystem. As a result of our research aimed to identify whether there is a semantic relationship between the university and the regional entrepreneurial ecosystem, for the analyzed text, we found no reference relationships between the analyzed keywords. This could give us a perception regarding how significant is for the regional policy documents the interaction between the university and the other components of the entrepreneurial ecosystem.

Based on the analysed information from the literature review, we assumed that the regional strategic development documents are reflecting at semantic level the role of universities in creating a regional entrepreneurial ecosystem.

The term entrepreneurial ecosystem was initially conceived by James Moore in an article in the Harvard Business Review published in the 1990s (Mason C., Brown R., 2014). James Moore extends the systematic biology approach to the economy and introduces the concept of "business ecosystem", explaining the success of capital concentration, consumer interest, and the talent created by new innovation (Moore, 1993, p.76).

In the context of developing and promoting entrepreneurship, the importance given to universities is growing. From the perspective of entrepreneurial ecosystems, higher education institutions interact with the other components of the entrepreneurial environment (organizations, institutions, individuals, entrepreneurial processes), especially through their role as a provider / creator of knowledge. 


\section{LITERATURE REVIEW}

The goal in reviewing the literature was to assessing the interest of existing academic research on the role / relationship of universities in entrepreneurial ecosystems.

To achieve this goal, two research directions were pursued:

An analysis of the literature on the emergence and significance of the concept of entrepreneurial ecosystem.
To achieve this, a search was made using the word "entrepreneurial ecosystem concept history" using the Google Scholars search engine.

From a total of the 57,900 search engine results, were selected the top 20, relevant to the frequency of the word "entrepreneurial". From these, were found and analyzed 11 scientific articles which deal with the topic of interest for this study. The approaches in formulating the concept of entrepreneurial ecosystem synthesized from this analysis are presented in the chronological order of occurrence, in Table 1.

Table 1. Developments in formulating the concept of entrepreneurial ecosystem

\begin{tabular}{|c|c|c|}
\hline & Author & Developments in Entrepreneurial Ecosystem concept \\
\hline 1. & $\begin{array}{l}\text { James F.Moore, } \\
1993\end{array}$ & $\begin{array}{l}\text { Expands the systematic approach of biology in the economy and introduce the concept of "business } \\
\text { ecosystem", which explains the success resulting from the concentration of capital, consumer interest and } \\
\text { talent generated a new innovation. }\end{array}$ \\
\hline 2. & $\begin{array}{l}\text { Inge Ropke, } \\
2004\end{array}$ & $\begin{array}{l}\text { It analyzes the evolution of the ecological economy as a distinct field of research and the influence of the } \\
\text { ecosystem concept in the economy-environment relationship. }\end{array}$ \\
\hline 3. & $\begin{array}{l}\text { James F.Moore, } \\
2006\end{array}$ & $\begin{array}{l}\text { Identifies the challenges of the entrepreneurial ecosystem in the context of the evolution of the IT \& } \mathrm{C} \\
\text { industry. }\end{array}$ \\
\hline 4. & $\begin{array}{l}\text { Lamar Pierce, } \\
\quad 2009\end{array}$ & $\begin{array}{l}\text { He believes that "a traditional industry or market can contain many ecosystems that overlap around central } \\
\text { firms." From this perspective, the strategic decisions of central firms in the ecosystem can have decisive } \\
\text { effects on niche markets within their ecosystem. }\end{array}$ \\
\hline 5. & $\begin{array}{l}\text { Daniel J. } \\
\text { Isenberg, } 2010\end{array}$ & $\begin{array}{l}\text { It is the first to highlight the holistic aspect of the entrepreneurial ecosystem; identifies six areas within the } \\
\text { entrepreneurial system: a favorable culture that allows policies and leadership, the availability of adequate } \\
\text { funding, quality human capital, product markets and a range of institutional support. }\end{array}$ \\
\hline 6. & $\begin{array}{l}\text { Peter Vogel, } \\
2013\end{array}$ & $\begin{array}{l}\text { The entrepreneurial ecosystem is "an interactive community in a geographic region, composed of different } \\
\text { and interdependent actors (e.g. entrepreneurs, institutions and organizations) and factors (such as markets, } \\
\text { regulatory framework, support setting, entrepreneurial culture) that evolve over time and whose actors and } \\
\text { factors coexist and interact to promote the creation of new firms ". }\end{array}$ \\
\hline 7. & $\begin{array}{l}\text { Candida G. } \\
\text { Brush, } 2014\end{array}$ & $\begin{array}{l}\text { Explore the concept of an entrepreneurial education ecosystem in which universities play a central role. The } \\
\text { U-BEE structure (university based entrepreneurship ecosystem) includes several individual levels (student, } \\
\text { faculty, staff, administration), groups (faculty, students), organizations (incubators, centers), community } \\
\text { events and stakeholders (government, founders). }\end{array}$ \\
\hline 8. & $\begin{array}{l}\text { Colin Mason } \\
\text { and Ross } \\
\text { Brown, } 2014\end{array}$ & $\begin{array}{l}\text { „a set of interconnected entrepreneurial actors (both potential and existing), entrepreneurial organisations (e.g. } \\
\text { firms, venture capitalists, business angels, banks), institutions (universities, public sector agencies, financial } \\
\text { bodies) and entrepreneurial processes (e.g. the business birth rate, numbers of high growth firms, levels of } \\
\text { 'blockbuster entrepreneurship', number of serial entrepreneurs, degree of sell-out mentality within firms and } \\
\text { levels of entrepreneurial ambition) which formally and informally coalesce to connect, mediate and govern } \\
\text { the performance within the local entrepreneurial environment”. }\end{array}$ \\
\hline 9. & $\begin{array}{c}\text { Ben Spigel, } \\
2015\end{array}$ & $\begin{array}{l}\text { "Entrepreneurial ecosystems are combinations of social, political, economic, and cultural elements within a } \\
\text { region that support the development and growth of innovative start-ups and encourage nascent entrepreneurs } \\
\text { and other actors to take the risks of starting, funding, and otherwise assisting high-risk ventures." } \\
\text { Notes the harmonious link between the concepts of entrepreneurial ecosystem, cluster and regional innovation } \\
\text { systems. Along with facilities and support services, government policies and open markets, universities are } \\
\text { considered a "material attribute" of entrepreneurial ecosystems. Universities can develop new technologies } \\
\text { and create entrepreneurial opportunities. }\end{array}$ \\
\hline 10. & $\begin{array}{l}\text { Zoltan J. Acs \& } \\
\text { Erik Stam \& } \\
\text { David B. } \\
\text { Audretsch \& } \\
\quad \text { Allan } \\
\text { O’Connor, } 2017\end{array}$ & $\begin{array}{l}\text { Considers two lineages: the literature on strategy and literature on development. Both directions share the } \\
\text { roots in the thinking of ecological systems, focusing on the interdependence of actors in a particular } \\
\text { community to create new value and developing a new approach to industrial organization over the last } \\
\text { decades. } \\
\text { Addressing the entrepreneurial ecosystem emphasizes the interdependence between actors and factors, but } \\
\text { considers entrepreneurship as the main outcome of the entrepreneurial ecosystem. }\end{array}$ \\
\hline
\end{tabular}




\begin{tabular}{|c|c|c|}
\hline & Author & Developments in Entrepreneurial Ecosystem concept \\
\hline 11. & $\begin{array}{c}\text { Ross Brown \& } \\
\text { Colin Mason, } \\
2017\end{array}$ & $\begin{array}{c}\text { It synthesizes a dichotomous conceptual framework of two types of diametrically opposed or "idealized" } \\
\text { ecosystems: embryonic ecosystems and scale-up ecosystems. Embryonic ecosystems are the most common } \\
\text { entrepreneurial ecosystems. Typically, these areas are characterized by a relatively modest level of growth- } \\
\text { oriented entrepreneurship, unlike the developed ecosystem type, characterized by a high level of } \\
\text { entrepreneurial orientation and high-tech start-ups }\end{array}$ \\
\hline
\end{tabular}

b). An evaluation based on a bibliometric study conducted through an electronic search on the Science Citation Index and SCOPUS platform.

including a journal is the number of citations it receives, which gives certain guarantees as the scientific relevance of the research results. The search on the Science Citation Index

These databases provide a high coverage of all areas of scientific research; contain information about citations and the institutional addresses of all authors of a particular article, thus providing the conditions for a deeper analysis. The criterion for platform was made using the words: "entrepreneurial ecosystem" and "university". Table 2 shows the identified journals and the number of articles found resulting from the search

Table 2. Identified journals and the number of articles for key words "entrepreneurial ecosystem" and "university

\begin{tabular}{|c|c|c|c|}
\hline Journals & $\begin{array}{c}\text { Article numbers for } \\
\text { "university" search } \\
\text { criteria }\end{array}$ & $\begin{array}{c}\text { Article numbers } \\
\text { "entrepreneurial } \\
\text { ecosystem" search } \\
\text { criteria }\end{array}$ & Period \\
\hline Entrepreneurial business and economic review & 175 & 0 & $2013-2017$ \\
\hline International Journal of Entrepreneurial Behavior & 35 & 38 & $1995-2017$ \\
\hline Strategic Change - briefings in entrepreneurial \\
finance & 923 & 20 & $1999-2017$ \\
\hline Entrepreneurship Theory and Practice & 839 & 27 & $2002-2017$ \\
\hline Strategic Entrepreneurship Journal & 267 & 38 & $2002-2017$ \\
\hline Foundations and Trends in Entrepreneurship & 48 & 1 & $2005-2017$ \\
\hline Entrepreneurship \& Regional Development & 746 & 30 & $1989-2017$ \\
\hline International Journal of Gender and \\
Entrepreneurship
\end{tabular}

\section{METHODS}

Using the method of qualitative analysis, respectively the semantic analysis method, the study analyzes the role of universities from the North East region of Romania in creating the regional entrepreneurial ecosystem through the influence of regional development strategies.

\subsection{Formulate Hypothesis}

Before starting the qualitative research, based on the studies mentioned in table no.1, the assumed hypothesis is:

H1: The regional strategic development documents are reflecting at semantic level the role of universities in creating a regional entrepreneurial ecosystem.

\subsection{Design Research}

To achieve the research objective, a semantic analysis was carried out for the Romanian version of "North-East Regional Strategy for Research and Innovation through Smart Specialization RIS 3". The following steps in the research are: identification of analysis units (NE region), choice of a set of categories (REDI pillars and interaction with the university), identification and classification of the found references, analysis of the relations of the references used, and synthesis of the conclusions. For this purpose we used the TROPES v.8.2 semantic analysis program.

The "North-East Regional Strategy for Research and Innovation through Smart Specialization RIS 3" (November 2017 edition) is based on the information included in the "Regional Strategic Framework Document for Regional Research and Innovation through Smart Specialization of the North-East Region, Romania", dated June 9, 2017. The document is the result of public consultations initiated by Agency for Regional Development in the North-East Development Region of Romania.

In recent years, interest in entrepreneurship and its comparative assessment across countries has led to the emergence of several indicators and indicators, including:

- GEDI (Global Entrepreneurship and Development Index), GEM (Global Entrepreneurship Monitor), Eurobarometer Survey on Entrepreneurship

- REDI (Regional Entrepreneurship and Development Index), is a composite index developed at the request of the European Commission by four well-known research institutions (University of Groningen, University College London, University of Pécs, Utrecht University) that assess the development of entrepreneurship by regions in the EU member states.

For our study we chose the Regional Entrepreneurship and Development Index (REDI), considering being relevant for regional development. This index is structured in the following sub-indices: attitudes, abilities and aspirations. Each sub-index is composed of the following pillars shown in the table no.3. We used the definitions of the three pillars as reference words for the semantic analyze of Smart Specialization Strategy for North-East Region RIS3, Romania.

Qualitative analysis using the Tropes program had the following stages:

1. Identification of references.

2. Analysis of relations between references

For the Tropes program, references are nouns bearing relevant information. Using this tool, we want to know what does 59 
"North-East Regional Strategy for Research and Innovation through Smart Specialization RIS 3" says about the university as well about as the REDI pillars.
Thus, the decreasing order of concepts, by frequency, by exploring the relations between them, is presented in Table 3 .

Table 3. Frequency of keywords in text "North-East Regional Strategy for Research and Innovation through Smart Specialization RIS 3

\begin{tabular}{|c|c|c|}
\hline Regional & keywords & Frequency \\
Entrepreneurship and & & 77 \\
Development Index & & 17 \\
\cline { 2 - 3 } REDI & University/universities & 10 \\
\cline { 2 - 3 } & (Innovation) Ecosystem & 10 \\
\cline { 2 - 3 } & Risk & 6 \\
\cline { 2 - 3 } Entrepreneurial \\
Attitudes & Oportunity & 4 \\
\cline { 2 - 3 } & Atitude & 18 \\
\cline { 2 - 3 } & Networks/networking & 11 \\
\cline { 2 - 3 } & Start-up & 12 \\
\hline \multirow{4}{*}{\begin{tabular}{c} 
Entrepreneurial Abilities \\
\cline { 2 - 3 }
\end{tabular}} & Culture & 237 \\
\cline { 2 - 3 } & Inovation & 102 \\
\cline { 2 - 3 } & Technology & 3 \\
\hline \multirow{3}{*}{$\begin{array}{c}\text { Entrepreneurial } \\
\text { Aspirations }\end{array}$} & Human Resources & 33 \\
\cline { 2 - 3 } & Competition & 285 \\
\cline { 2 - 3 } & Funding & 3 \\
\cline { 2 - 3 } & Development & 4 \\
\cline { 2 - 3 } & Proces innovation & 3 \\
\hline
\end{tabular}

For the text we analyzed, we tried to identify the frequency of references, to highlight the key concepts. We looked for the answer to the question: how does the "university" relate to each of the other references analyzed?

We considered "university" word both as a concept (central reference) and also as a reference in order to seek for relations between references. The relations of each reference mean how connections are grouped around the central concept. This is a clue for the emphasis granted by the author to these concepts.

The analysis reveals that:

- the most frequent key terms are: "growth" 285, "innovation" 237, "technology" 102, "university / universities" 94

- less likely to use the terms: "competition" 3, product innovation, process innovation 3 , attitude 4, opportunity 6 , words that have semantic potential in relation to the subject of the study

- no reference relationships between the analyzed keywords have been identified, showing poor interest on behalf of the text's author regarding connecting the keywords.

\section{RESULTS}

Overall, the results of this study show that:

Regarding the entrepreneurial ecosystem concept developments, we found a growing interest (especially since 2010) for the holistic approach to the concept of entrepreneurial ecosystem;

The number of articles that include the keyword "university" is 923 articles in Strategic Change - briefings in entrepreneurial finance, occurring between 1999-2017;
The number of articles that include the keyword "entrepreneurial ecosystem" is 38 articles in the International Journal of Entrepreneurial Behavior (occurring between 19952017) and 38 articles in the Strategic Entrepreneurship Journal (occurring between 2002-2017);

Table 3 shows that keyword "university / universities" is one of the most frequent used in the "North-East Regional Strategy for Research and Innovation through Smart Specialization RIS 3";

No reference relationship between the analyzed keywords has been identified.

\section{CONCLUSIONS}

Developments in the concept of entrepreneurial ecosystem suggest an increasing interest in a holistic approach, integrating the contours of natural science (where the concept originates) into the complexity of the economic, social, cultural and political landscape.

There is a much higher number of articles that include the keyword "university" (923 articles in Strategic Change briefings in entrepreneurial finance, occurring between 19992017), compared to the number of articles that include the keyword "entrepreneurial ecosystem" (38 articles in the International Journal of Entrepreneurial Behavior, 38 articles in the Strategic Entrepreneurship Journal), reflecting an increased interest of researchers towards the university and its role in the entrepreneurial development of communities. On the other hand, the lower number of articles having the "entrepreneurial ecosystem" search criterion can be justified by the relatively recent but growing interest in this concept.

The results are not confirming the initial hypothesis, which means that for the North East region of Romania, the regional strategic development documents are not reflecting at semantic 60 
level the role of universities in creating a regional entrepreneurial ecosystem.

The lack of a reference relationship between the keywords analyzed in the semantic analysis of the "North-East Regional Strategy for Research and Innovation through Smart Specialization RIS 3" can justify us considering that it may be a reflection on the content of a strategic planning document, the fact that the North-East region is the last one in the ranking of the regions in the E.U. in terms of REDI indicator, at the level of 2013 (18.4 compared to the first place, with 82.2).

The main limit of this study is that semantic analysis refers to a single programming document at the NE region level. One of the motivations would be that it is the only document that conceptually represents the development policy through smart specialization existing in this region. Also, the relationship between text and reality cannot be reduced to semantic interpretation. Research should be continued with the analysis of other relevant documents for the regional development policy.

We explored the interaction between the university and the other components of the entrepreneurial ecosystem, from a semantic perspective. The literature review confirms the researcher's interest towards the university and its role in the entrepreneurial development of communities and also an increasing interest for studying entrepreneurial ecosystems. Also, in terms of number of articles analyzed, topic targeting keyword research "university" show more interest in this research topic than research targeting the keyword "entrepreneurial ecosystem".

Using Tropes software, the qualitative analyses aimed to find and show the occurrences and relationships between the selected keywords (significant for attitudes, abilities and aspirations) as a conceptual representation of assessing the development of entrepreneurship by regions. The results did not confirm that for the North East region of Romania, the regional strategic development documents are reflecting at semantic level the role of universities in creating a regional entrepreneurial ecosystem. These findings contribute to a better understanding of the role of universities in the development of an entrepreneurial environment, especially in the Eastern Europe countries and also could suggest improvements in the regional development policies.

In the light of these findings, future qualitative inferences can be formulated in order to compare the interaction between the university and the other components of the entrepreneurial ecosystem, for other E.U regions.

\section{REFERENCES}

1. Acs Z.,C., Stam E., Audretsch, D.B., O'Connor A., The Lineages of the Entrepreneurial Ecosystem Approach, Small Business Economics (49), 1, pp.1-10, (2017).
2. Birch, D. L. The Job Generating Process. Cambridge, Mass.: M.I.T. Program on Neighbourhood and Regional Change, (1979).

3. Brown R., Mason C., Looking inside the spiky bits: a critical review and conceptualisation of entrepreneurial ecosystems, Small Business and Economics (49), pp.11-30, (2017).

4. Brush, C. Exploring The Concept Of An Entrepreneurship Education System. in S. H. Kuratko, Innovative Pathways for University Entrepreneurship in the 21st Century, Vol.24, pp. 25-39, Emerald Group Publishing Limited, (2014).

5. Cohen, B. Sustainable Valley Entrepreneurial Ecosystems. Business Strategy and the Environment, www.interscience,wiley.com, (2005).ti M., L. R. Strategy as Ecology, Business Review, pp. 68-79, (2004).

6. Iansiti M.,L.R. (2004). Strategy as Ecology. Business Review, pp. 68-69

7. Isenberg, D. J. How to Start an Entrepreneurial Revolution. Harvard Business Review, 4, (2010).

8. Mason C., Brown R., Entrepreneurial Ecosystems and Growth Oriented Entrepreneurship, OECD LEED Programme and the Dutch Ministry of Economic Affairs, (2014).

9. Moore, J. (1993), Predators and prey: a new ecology of competition. Harvard Business Review, pp. 75-86.

10. Moore, J., Business Ecosystems and the View from the Firm;51,1. Antitrust Bulletin, pp. 31-76, (2006).

11. Pierce, L.,Big Losses in Ecosystems Niches:How Core Firm Decisions Drive Complementary Products Shakeouts. Strategic Management Journal;30, pp. 323-347, (2009).

12. Ropke, I. The Early History of Modern Ecological Economics. Ecological Economics 50, pp. 293-314, (2004).

13. Spigel, B. The Relational Organization Of Entrepreneurial Systems, Entrepreneurship Theory and Practice, 41(1), pp. 49-72, (2015).

14. Spilling, O. The Entrepreneurial System: on entrepreneurship in the context of a mega-event. Journal of Business Research, pp. 91-103, (1996).

15. Vogel, P., The Employment Outlook for Youth:Building Entrepreneurial Ecosystems as a Way Forward. Conference Proceedings of the G20 Youth Forum pp. 443449, G8 / G20 Alumni Association, (2013).

16. Szerb, L., Acs.,Z., Autio, E., Ortega-Argilés,R., Komlósi, É., (2013). European Commission. REDI: The Regional Entrepreneurship and Development Index - Measuring regional entrepreneurship Final Report retrieved from http:/ec.europa.eu/regional policy/sources/docgener/studi es/pdf/regional entrepreneurship development index.pdf

17. Strategia pentru Cercetare și Inovare Regională prin Specializare Inteligentă RIS3 NORD-EST.2017. Retrieved from: http://adrnordest.ro/user/file/news/17/RIS3 NordEst $05 \quad 12$ 2017.pdf 